Seminário de Pesquisa

Programa de Pós-Graduação

Design FAU USP

\title{
Design de Serviço e a lacuna na inclusão de pessoas com deficiência
}

\author{
Diego Normandi Maciel Dutra, Cibele Haddad Taralli
}

\author{
design de serviço; pessoa com deficiência; ferramentas; \\ metodologia; inclusão
}

O Design de Serviço tem ganho destaque e consistência no campo profissional e nas pesquisas acadêmicas. Encarando o tema como uma abordagem, podemos identificar sua presença nos mais variados segmentos do Design, desde o projeto de produtos, passando pelo universo gráfico e digital, até no Design para Inovação Social. Entretanto, notamos que há uma lacuna considerável dentre as questões de atuação do Design de Serviço: a inclusão de pessoas com deficiência. A exclusão desse público não está somente

Curso

Doutorado

\section{Linha de Pesquisa}

Design: Processos e Linguagens

\section{Diego Normandi Maciel Dutra}

Doutorando em Design pela FAUUSP, com tema de pesquisa sobre Design de Serviço e inclusão de pessoas com deficiência no cinema. Bolsista FAPESP, e professor do MBA em Design da Universidade de Fortaleza. e-mail: diegonmd@usp.br Lattes: http://lattes.cnpq. $\mathrm{br} / 5520336797190780$

Orcid: https://orcid.org/00000002-3439-3602

\section{Cibele Haddad Taralli}

Professora Sênior e docente do PPGDESIGN da FAUUSP nas seguintes áreas de pesquisa e abordagens: arquitetura; design do produto; design social e de serviços; design e ensino; design centrado no usuário/humano; design, ambiente e espaços; processos e procedimentos de pesquisa e design.

e-mail: cibelet@usp.br

Lattes: http://lattes.cnpq. $\mathrm{br} / 6016190566941978$

Orcid: https://orcid.org/00000002-5330-0387 nos resultados a ele entregues, mas também nos procedimentos relacionados à investigação, cocriação, coprodução, ao codesign, bem como com nos métodos de coleta e análise de dados. A investigação de Doutorado que abraça este trabalho identificou que dentre as principais referências bibliográficas sobre Design de Serviço, bem como as principais ferramentas de coleta de dados e proposição de soluções desconsideram as condições sensoriais dos atores envolvidos nesses processos, de forma que por mais que o Design de Serviço seja divulgado como uma abordagem holística e cocriativa, aquele público ainda não conta com ferramentas adequadas à sua participação e empoderamento quanto ao desenvolvimento de serviços. Assim, este trabalho busca chamar a atenção para a necessidade de inclusão, por meio da criação e/ou adaptação de métodos de coleta de dados e proposição de soluções de Design apropriadas às características de interação de pessoas com e sem deficiência sensorial, numa perspectiva inclusiva, bem como apresentar métodos que estão sendo usados na pesquisa de Doutorado. 


\section{Service Design and the gap about inclusion of people with disabilities}

Diego Normandi Maciel Dutra, Cibele Haddad Taralli

service design; people with disabilities; tools; methodology; inclusion

Service Design has gained prominence and consistency in the professional field and in academic research. Facing the theme as an approach, we can identify its presence in the most varied segments of Design - from Product Design, through the Graphic and Digital, to Design for Social Innovation. However, we noticed that there is a considerable gap among the Service Design issues: the inclusion of people with disabilities (or disabled people). The exclusion of this public is not perceived only in the results delivered to people, but also in the procedures related to investigation, co-creation, co-production, codesign, as well as through the methods of data collection and analysis. The PhD investigation that embraces this work identified that the main bibliographic references on Service Design, as well as the main data collection and solutions proposal tools, do not consider the sensory conditions of the actors involved in these processes, so that even though Service Design is promoted as a holistic and co-creative approach, disabled people does not yet have adequate tools for their participation and empowerment regarding the development of services. Thus, this work seeks to draw attention to the need for inclusion, by creating and / or adapting data collection methods and proposing appropriate Design solutions to the interaction of people with and without sensory disabilities, in an inclusive perspective, as well as presenting methods that we are using in the PhD research.

\section{Referências | References}

PENIN, L. 2018. Designing the invisible. London: Bloomsbury.

POLAINE, A.; LAVRANS, L. \& REASON, B. 2013. From Insight to Implementation Service Design. New York: Rosenfeld Media.

ROGERS, Y.; SHARP, H. \& PREECE, J 2013. Design de Interação. Porto Alegre: Bookman.

STICKDORN, M. et al. 2018. This is service design doing: Applying service design thinking in the real world. Sebastopol: O'Reilly.

STICKDORN, M. \& SCHNEIDER, J. 2011. This is service design thinking. Amsterdam: BIS Publishers.

\section{Cibele Haddad Taralli}

Senior Professor and professor at FAUUSP's PPGDESIGN in the following research areas and approaches: architecture; product design; social and service design; design and teaching; human/usercentered design; design, spaces, and environment; research and design processes and procedures. e-mail: cibelet@usp.br

Lattes: http://lattes.cnpq. br/6016190566941978

Orcid: https://orcid.org/00000002-5330-0387 